\title{
Personality Traits and Academic Motivation of Students with Behavior Concerns in a Catholic High School
}

\author{
Rita G. Mariano, MSLT ${ }^{1}$ and Ma. Wilma M. Maravilla ${ }^{2}$ \\ ${ }^{1}$ St. Michael High School of Culasi, Inc., Antique, Philippines \\ 2University of Negros Occidental-Recoletos, Bacolod City, Philippines
}

\begin{tabular}{l} 
Article history \\
Submitted: 24 July 2020 \\
Revised: 11 November 2020 \\
Accepted: 13 November 2020 \\
\hline Keywords \\
Guidance and Counseling \\
Personality Traits \\
Academic Motivation \\
Behavior Concerns \\
High School Students \\
Diocesan School \\
Descriptive-Correlational \\
Antique
\end{tabular}

Introduction. Personality traits reflect people's characteristic patterns of thoughts, feelings, and behaviors. The traits relevant to personality are considered to be steady throughout the work of life as suggested in the Five-Factor Model, which identifies any of the five traits a person may exhibit, namely Openness to experience, Conscientiousness, Extraversion, Agreeableness, and Neuroticism (OCEAN), (Costa \& McCrae, 2003). On the other hand, academic motivation is the student's desire, as reflected in his approach, persistence, and level of interest regarding academic subjects when his competence is judged against a standard of performance. Students with behavior concerns are those who underwent disciplinary action due to misdemeanor. Their delinquency may be related to their personality traits, demographics, or lack of academic motivation. Hence, the paper identified the dominant personality traits and assessed 40 male high school students' academic motivation with behavior concerns in a Catholic school in Antique during the School Year 20192020. Likewise, it explores the difference in academic motivation level when grouped according to demographic variables, namely, family monthly income, family structure, and type of misdemeanor. Also, it determines the relationship between personality traits and academic motivation of students with behavior concerns.

Methods. A descriptive, comparative, correlational research design was used to describe, compare, and correlate the dominant personality traits and academic motivation of high school students with behavior concerns enrolled in a Catholic School in Antique during the school year 2019-2020 using purposive sampling. The data were gathered using standardized tests, namely, the Big Five Personality Inventory revised by John and Srivastava (1999) and Academic Motivation Scale by Vallerand et al. (1992) for academic motivation. Mean, Standard Deviation, Mann Whitney U test, and Chi-square test of association were used to analyze the data.

Results. The study's findings revealed that the majority of the respondents came from low-income families and had committed minor offenses. However, the majority also came from intact families. Among the Big Five Personality Factors, the majority of respondents were predominantly "agreeable," and the least group were the "extraverts." In terms of academic motivation, these wrongdoers generally had a very high level of motivation regardless of demographics, namely, family monthly income, family structure, and type of misdemeanor. When grouped according to the demographics as mentioned earlier, no significant difference in their level of motivation was generally noted, except in the area of amotivation (lower score indicates lower motivation level) where respondents coming from non-intact families were significantly have lower motivation level than those from intact families. Also, no significant relationship was found in the dominant personality traits and academic motivation; thus, personality trait does not influence academic motivation.

Conclusion. Gleaned from the study's findings, it is implied that the lack of financial resources may predispose some students to misdemeanors because their needs are not easily met. It is also not a guarantee that an intact family structure can keep students from delinquency, especially when there are ongoing or looming family conflicts. In terms of traits, friendly and trusting students may be prone to commit offenses, especially when friends are delinquent themselves. For the participants with behavior concerns, the academic motivational level is not related to the family's financial resources or misdemeanor. However, being a delinquent and, at the same time, coming from a non-intact 
family may lead to a lack of academic motivation since parental presence plays a significant role in the students' academic journey. Finally, the findings did not support the theory that a dominant personality trait is related to academic motivation. Whatever dominant trait one possesses (being open to experience, conscientious, extravert, and agreeable) does not influence his or her level of academic motivation. Overall, early intervention should be addressed through a useful guidance and counseling program to help students cope with the challenging life ahead.

Practical Value of the Paper. This study's findings served as the basis of a Proposed Counseling Intervention Program useful to guidance counselors, in collaboration with the discipline moderator in promoting academic motivation among the students, especially those with behavior concerns.

\section{References}

Arkee, Costelo, \& Simeonova (2018). How does household income affect child personality traits and behaviors? Article in American Economic Review.www.researchgate.net/publication,323494867

Chapman, Duberstein, Sorensen, \& Lyness (2007). Gender differences in five-factor model personality traits in an elderly cohort: extension of robust and surprising findings to an older generation. Pers indivi.Dif...2007 Oct; 43(6), 1594-1603.

Grant, Potenza, \& Dessai (1011). Stealing among high school students: Prevalence and \&clinical Correlates. Article in the Journal of the American Academy of Psychiatry and the Law 39(1)-44

Harakeh, Z., Scholte, R., HJ Vries, H., Engels, R., C.M.E., (2005). Personality traits in early adolescence. J Pers Social Psychology. Doi: 10.1037/a0038497

Hidi, S. \& Harackiewicz, J. M. (2000). Motivating the academically unmotivated: A critical issue for the 21st century. Review of Educational Research 70(2), 151-179. doi:10.3102/00346543070002151

John, O. P., \& Srivastava, S. (1999). The Big-Five trait taxonomy: History, measurement, and theoretical perspectives. In L. A. Pervin \& O. P. John (Eds.), Handbook of personality: Theory and research (Vol. 2, pp. 102-138). New York: Guilford Press.

Komarraju, M., Karau, S. J., \& Schmeck, R. R. (2009). Role of the Big Five personality traits in predicting college students' academic motivation and achievement. Learning and Individual Differences, 19, 47-52.

Legault, L., Green-Demers, I., \& Pelletier, L. (2006). Why do high school students lack motivation in the classroom? Toward an understanding of academic amotivation and the role of social support. Journal of Educational Psychology 98(3), 567-582. doi:10.1037/0022-0663.98.3.567

McCrae, R. R., \& Costa, P. T., Jr. (2003). Personality in adulthood: A five-factor theory perspective (2nd ed.). Guilford Press. https://doi.org/10.4324/9780203428412

Vallerand, R. J., Pelletier, L. G., Blais, M. R., Brière, N. M., Senécal, C. B., \& Vallières, É. F. (1992). The Academic Motivation Scale: A Measure of Intrinsic, Extrinsic, and Amotivation in Education. Educational and Psychological Measurement. 52. 1003-1003. 10.1177/0013164492052004025.

\section{Correspondence:}

Rita G. Mariano, MSLT [mrita9710@gmail.com]

http://orcid.org/0000-0002-3320-2210 